\title{
Recent Developments and Debates in Korean Prehistoric Archaeology
}

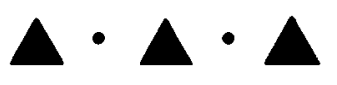

SEUNG-OG KIM

\section{INTRODUCTION}

Held in the year 2000, the 24th Annual Conference of the Korean ArchaeoLOGiCAl Society focused on "The Direction of Korean Archaeology in the 21st Century." The conference provided a chance to broadly review the establishment and development of twentieth-century Korean archaeology, which had occurred within the broad contexts of a Japanese colonial invasion, continuing division between North and South Korea, North Korea's isolation, and the democratization of South Korea (K.-M. Yi 2000). In addition, themes and issues facing Korean archaeology in the new millennium were considered, such as informatization, scientification, globalization, the archaeology of unification, and environmental issues. Accordingly, if the twentieth century was considered the period during which the foundation and development of Korean archaeology had taken place, then it could be expected that the twenty-first century would see the establishment of Korean archaeology within the global archaeological context. By the year 2000, in tune with wider trends of informatization and globalization, this was already under way.

As a discipline, Korean archaeology underwent a paradigm shift at the same time as the quality of archaeological work improved greatly after the 1990s. Regulations concerning buried cultural properties were revised in the 1990s as large-scale land development was occurring. The result was that the number of investigations of buried cultural properties increased rapidly and large-scale sites were excavated. Since then, the number of archaeologists involved in investigating and conducting research on buried cultural properties has continued to increase. ${ }^{1}$ They have brought about a golden age in Korean archaeology, at least in terms of the amount of archaeological data available. As the archaeological archives have become more plentiful, they have nourished the discipline, leading to an increase in the number and quality of published research articles on Korea's past culture and history.

The rapid increase in the number of excavations and in the amount of research materials since the 1990s has fortunately been accompanied by both diversification and greater intensification of research themes. The aim of this article is to examine the developments and debates that have taken place in Korean prehistoric archaeology 
Table i. Chronological Scheme for Korean Prehistory

\begin{tabular}{ll}
\hline PERIOD & \multicolumn{1}{c}{ DATE } \\
\hline Palaeolithic & $700,000 ?-10,000$ B.C. \\
Neolithic (Chulmun) & $10,000 ?-1500$ B.C. \\
Bronze Age (Mumun) & $1500-300$ B.C. \\
Early Iron Age (Late Bronze Age) & $300-100$ B.C. \\
\hline
\end{tabular}

since the 1990s. It would be impossible to discuss all the developments and debates within Korean prehistoric archaeology that have occurred over the past quarter century within a single journal article. I therefore focus mainly on what has taken place since the turn of the millennium, while noting that the developments and debates of the late 1990s have continued into the early twenty-first century.

In this article, I first examine developments in research on distinct archaeological periods within the broad span of prehistoric time from the Palaeolithic to the Early Iron Age. This is followed by a synthesis of trends in archaeological methods and research issues that affect all periods of Korean prehistoric archaeology. The discussion of recent trends in research methods and other topics of interest in Korean archaeology is based on key papers and volumes that have been recently published on the specific periods of prehistory listed in Table 1.

\section{PREHISTORIC KOREA: DEVELOPMENTS AND DEBATES}

\section{Palaeolithic Archaeology}

Debate Surrounding the Middle to Late Palaeolithic Transition - Korean archaeologists find it difficult to identify a Middle Palaeolithic, in line with the "Lower-MiddleUpper" Palaeolithic chronology of European archaeology, in the Korean Palaeolithic context. ${ }^{2}$ For example, expressing doubts about the establishment of a Middle Palaeolithic phase, Sun-Ju Park (1999) suggests a two-part chronology, naming the period before 30,000 years ago the "Early Palaeolithic" and the following period the "Late Palaeolithic." Seon-Bok Yi (2001) also sees a three-period "Lower-Middle-Upper" system as inappropriate and attempted to define a new cultural classification for the early and middle periods. Finally, noting that the existence of any specific technology or cultural traits that might be termed Middle Palaeolithic remains unclear, ChunTaek Seong (2002a) agrees with these scholars in doubting that a Middle Palaeolithic existed in the Korean Peninsula.

Other archaeologists maintain that the "Lower-Middle-Upper" chronological system is useful for research on the Korean Palaeolithic. Young-Chul Park (2001, 2002) posits continuity between an early "pebble chopper" culture and a later culture based on small-to-medium-sized flakes. He argues that a Middle Palaeolithic can be established based on this continuity. From an adaptationist perspective, Heon-Jong Lee (2000, 2002a, 2004) suggests that the Middle Palaeolithic can be defined as the period in which technological differentiation can be identified in the production of tools made of quartz pebbles, in that this type of rock was strategically chosen. He stresses the coexistence of this technology with a later blade lithic culture. Yong-Joon Chang (2004) also maintains a division between the Lower and Middle Palaeolithic, albeit for 
different reasons than Heon-Jong Lee (2000, 2002a, 2004) suggests. For example, he argues that, except for the continuity in quartz use, there are clear differences between the Lower Palaeolithic and the Middle Palaeolithic in terms of lithic types and their production methods. Various other authors have also attempted to determine cultural differences between Early, Middle, and Late phases based on the traditions of lithic production (e.g., S.-Y. Choi 2010; S.-T. Kim 2011). ${ }^{3}$

These debates about the Palaeolithic chronological system originate from difficulties in stratigraphically separating the Middle and Late Palaeolithic levels, as well as a lack of precision in absolute dating. Despite these methodological problems, scholars must continue to work toward resolving the issue of chronological phases in order to understand the processes by which Korean Palaeolithic cultures emerged and changed.

Issues of Dating Based on Soil Wedges and Aira-Tn Volcanic Ash - Methods for dating soil wedges and Aira-Tn volcanic ash are a current topic of lively debate in Korean Palaeolithic archaeology. Soil wedges form under cold climatic conditions, so are used as evidence of glacial conditions. Work has been actively carried out linking the chronology of the Upper Palaeolithic to soil wedges in upper stratigraphic layers. For example, with regard to the formation of Quaternary period horizons, soil wedges have been divided into upper and lower portions, the former dated to approximately 25,000-15,000 years ago and the latter to 75,000-55,000 years ago (Han 2003; J.-Y. Kim et al. 2002). The use of soil wedges as a means of dating continues to be a controversial issue, with arguments and adjustments put forth from both sides. For example, Kidong Bae (2004) maintains the position that since seasonal freezing and various other factors can cause the wedge shape, soil wedges found at archaeological sites do not necessarily indicate the cold climate of a glacial period. Even the researchers that support the use of this dating method do not agree that all of the upper-level wedges are the same date or that their dates should be assumed to be before 20,000-25,000 years ago (e.g., Seong 2004).

Another debate concerns the use of Aira-Tn volcanic ash as a dating method. Supporters note the appearance of an Aira-Tn ash layer across the Korean Peninsula, including at sites such as Jeongok-ri in Yeoncheon and Juwol-ri in Paju. They argue that the appearance of tanged points and microblades - material culture typical of the Late Palaeolithic - in layers above the Aira-Tn ash layer means that the ash layer can be used as a chronological marker (S.-B. Yi 1999, 2000). However, others rebut this claim by noting the possibility that plant opal phytoliths or nonvolcanic silica crystals may be mistaken for Aira-Tn ash, so small amounts of ash cannot be used to date specific cultural layers (Bae 1999).

These discussions about soil wedges and Aira-Tn volcanic ash seem to be strongly related to mistrust of AMS ${ }^{14} \mathrm{C}$ dating and its error range. One example is the case of Jeongok-ri, where the AMS dating results of soil wedges did not appear to be in the right sequence. Re-deposition or the disturbance of the stratigraphy by animal burrows have been posited as explanations for this situation (J.-C. Kim et al. 2002). In addition, after raising problems regarding the ${ }^{14} \mathrm{C}$ sequence of the Imjin River area's lava plateau, Seon-Bok Yi $(2010 a, 2011)$ has argued in favor of dating the Jeongok-ri site based on site formation processes and stratigraphy. Hence, an integrated analysis that includes a detailed understanding of site formation processes and stratigraphy is required in order to precisely determine the ages of Palaeolithic sites in Korea. 
Lithic Analysis and Zoo-Botanical Reconstruction - The starting point for Palaeolithic research has been analyses of lithics and lithic assemblages. These analyses are based on reconstructions of the types and manufacturing methods of lithics in relation to the technologies and subsistence, exchange, and cognitive systems of the period. So many lithic analyses have been been carried out in Korean Palaeolithic archaeology, it would be impossible to mention all of them here. For this reason, only the results of the most significant recent lithic analyses will be described in this section.

Currently, research into the types and functions of tanged points and hand axes is the subject of the liveliest debates. A large amount of work has been published on the distribution, production, and function of East Asia's most representative Upper Palaeolithic lithics, tanged points (G.-K. Lee 1999, 2011; H.-J. Lee 2002b; Lee and Jang 2011; Lee and Kong 2002). Research about the distribution and function of Acheulean hand axes is also ongoing; debate regarding their dating and the reality of the Movius Line as a terminus for hand axe production remains active (Choi 2006; Y.-J. Kim 2011; H.-W. Lee 2003; Norton et al. 2006; Yi 2010b). Amongst these studies, Yongwook Yoo and Dong-Wan Kim's (2010) attempt to explain the stylistic attributes of hand axes in terms of symmetrical variation can be regarded as a novel approach, breaking away from the technological focus of past studies and presenting a new analytical perspective. Finally, the work of Chuntaek Seong (2006), who has attempted to extract aspects of the composition and pattern of lithic assemblages by examining the assemblages of stratigraphic units rather than focusing on the presence or absence of certain lithic styles or describing deposition layers, is of significance.

Provenance studies of stone tools and use-wear analyses are also key research topics of recent interest in Korean Palaeolithic archaeology. Research is continuing on the qualities of obsidian tools and the provenance of the obsidian used in their manufacture (Chang 2013; Cho and Choi 2010; Jwa 2013; Y.-J. Lee et al. 2004; Yu et al. 2010). For example, the obsidian used to make tools found at Hawagye-ri in Hongcheon has been identified as having been obtained from Mount Baekdu (Choi and Yu 2005). Use-wear analyses are also actively ongoing (Hong and Kononenko 2005; Seong 2003), but it has been noted that each researcher examining use marks has applied his or her own subjective standards (Seong 2002). This problem must be overcome through scholarly discussion of comparative standards using microwear analysis.

Analyzing animal bones to reconstruct the Palaeolithic environment and culture has a long history in Western archaeology. In Korea, however, zooarchaeological studies on Palaeolithic animal bone assemblages have a relatively short history. The leading researcher in the analysis of animal bone material from Korean archaeological sites is Tae-Sop Cho. Analyzing material from a variety of sites, he has examined Palaeolithic fauna in reference to human activity, particularly the hunting economy (Cho 2000, 2013; Lee and Cho 2003). Chang-Gyun Han $(2008,2011)$ has also examined what botanical and faunal studies can tell us about the natural environment of the Palaeolithic period. However, Christopher J. Bae (2013) has noted that any analyses of associated faunal remains in Korea must be grounded firmly in taphonomic method and theory.

\section{The Neolithic Period}

Increased Research into Subsistence Economy and Diet - The most obvious change in recent research on the Korean Neolithic is the shift away from traditional typological 
and chronological work toward an interest in the subsistence economy and the environment. If we first consider research related to Neolithic agriculture, most work has focused on the specific characteristics of agriculture, rather than on routes of diffusion. For example, Sung-Mo Ahn (2002) examined the literature on famine relief crops and attempted a reconstruction of Neolithic vegetable foodstuffs. From this he concluded that by the middle of the Neolithic, millet-based field agriculture was already widespread across the Korean Peninsula. Following this, Sung-Mo Ahn (2005), like Chong-Pil Choi (2005), inferred that Neolithic agriculture was at the stage of small-scale cultivation within a hunter-gatherer economy and that the appearance of agriculture in the central southern region was due to environmental change and social factors. Additionally, an analysis of plant remains led Gyoung-Ah Lee and colleagues to hypothesize that, while there was cultivation of millet, Panicum, and legumes by the later mid-Neolithic period, the economic system was at a stage of pre-intensive, lowlevel cultivation (G.-A. Lee 2005; G.-A. Lee et al. 2011), a similar conclusion to that of Sung-Mo Ahn. June-Jeong Lee (2011) later refuted these models by arguing that the volume of Neolithic crop material indicates that the importance of mixed farming was relatively high in the Neolithic.

Beyond these important debates concerning the mix of nondomesticated and domesticated resources at Neolithic sites, a multitude of studies have explored possible diffusionary processes that might have resulted in different types of subsistence economies. For example, based on the composition of stone tools, one argument has been put forward to suggest that agriculture spread from the Liaoning region to the centralwest region of the Korean Peninsula and then extended into the inland southern region (J.-H. Choi 2005). Eun-Sook Song (2010) suggests that Korea's Comb-pattern pottery culture began through the diffusion of the complex hunter-gatherer culture of the Liao River region and the fishing-focused hunter-gatherer culture of the Russian Primorye. She argues that these cultures spread, respectively, into all regions of the Korean Peninsula through the Liao-Daedong River route and a route down the east coast of Korea. It has also been argued that sedentism predates agriculture in East Asia (S.-M. Ahn 2006).

In addition to agriculture, research on shell middens and their implications for the relative importance of shoreline resources, seasonality in economic activities, settlement patterns, and social organization has recently developed as an important area of archaeological inquiry. Methodological debates on the study of shell middens in Korea have been carried out, with criticisms lodged by some scholars regarding the uncritical application of foreign theories and models (G.-S. Kim 2004a), along with acknowledgment of the need to correctly apply foreign models (J.-S. Kim 2005). The most focused research on shell middens has been associated with function (J.-J. Lee $2002 a, b$ ). For example, the transition of Dongsam-dong shell midden into a center of production and exchange in the Middle Neolithic is viewed as having brought about changes in the subsistence patterns and the character of social groups residing there (J.-H. Choi 2010; Ha 2010). An interesting isotopic analysis suggests that in the south coast region, Neolithic populations occupied the shell middens year-round, while those on the west coast visited their shell middens seasonally or on a short-term basis (An 2011). There may have been significant variation in settlement permanency associated with shellfish harvesting in different regions.

Other research provides insight into the Neolithic diet. Examples include: identification of types of procured fish and animals, as well as plant remains, to infer the 
range of subsistence (Choi 2001; Ha 2001); analyses of animal bones excavated from shell middens (E. Lee 2010; J.-J. Lee 2003); analysis of mammal remains (C.-M. Lee 2011); analysis of the diet of humans whose remains have been found at shell midden sites (e.g., the Daepo shell midden study of H.-S. Kim 2010); and the estimation of seasonality through the analysis of fish bones (G.-S. Kim 2001). Some new approaches to understanding Neolithic subsistence strategies and their health consequences go beyond traditional studies of animal and plant materials. For example, diet and disease have been examined through the investigation of parasitic insects in coprolites (An et al. 2008), and trace element analyses of human skeletons (An 2009). Apart from working with food remnants and human remains, various studies of diet have also been carried out through the analysis of implements and pottery. These include: shell weights excavated from shell middens, interpreted as tools for catching the webfoot octopus rather than net sinkers (G.-S. Kim 2004b); harpoons, deduced as having been used by divers to catch fish (Y.-D. Lee 2006); Geumgang-type pottery, inferred to have been used for storing grain (Koo 2004); and medium-sized pottery, suggested as used for both cooking and storage, while large vessels primarily had a storage function (Choi 2011).

The Development of Chronological Research and the Establishment of New Chronological Schemes - The chronology of the Korean Neolithic has been based principally on pottery, with breakthroughs occurring because of continual discoveries of new material. The Gosan-ri site in Jeju Island, discovered in the 1990s, first gained the attention of archaeologists because it represents the earliest Neolithic transition. Artifacts at this site span the period between the very late Palaeolithic and the Early Neolithic. Through comparison with early pottery from the lower reaches of the Amur River in Russia and sites yielding the earliest types of Jomon pottery in Japan, the lower time limit of the Gosan-ri site has been set at 11,000-10,000 years ago (Kang 2002). Excavations at Gosan-ri continue to this day, with many questions still to be resolved. One thing we know for certain from this site is that the earliest Neolithic on the Korean Peninsula is much earlier than the previously accepted date.

Recent research on the earliest Neolithic sites and artifacts has turned the traditional two-phase chronological scheme for the early Neolithic upside-down. In traditional Neolithic chronology, the Incipient Neolithic is characterized by raised pattern pottery, which was replaced by the Osan-ri-style impressed pottery of the Early Neolithic. The archaeological community has been surprised by recent finds of early red burnished pottery, steamers, and rimmed pottery with horn-shaped handles in layers below the early raised pattern pottery levels at Jukbyun-ri in Uljin and Osan-ri C district in Yangyang and at the lowest levels at Munam-ri in Goseong and Bibong-ri in Changryeung. These discoveries have led to a reassessment of the cultural markers of the Incipient Neolithic (E.-Y. Kim 2007; Lim 2012). Sang-Taek Lim (2012) goes one step further by suggesting combining and categorizing Incipient Neolithic pottery according to its stylistic dimensions into Osan-ri style, Jukbyun style, and Dongsam-dong style (raised design pottery). Furthermore, there is evidence that the earliest two cultural phases actually coexisted in time in the East Coast region. If so, the present model of a transition of raised design pottery to Osan-ri-style impressed pottery becomes untenable. As a result, how to account for the gap between the lined pattern pottery phase of the Middle Neolithic and these newly established early phases has become an open question that needs to be addressed as soon as possible to establish clarity in cultural sequences (D.-J. Lee 2011). 
The Discovery of Large-Scale Settlements and Burial Grounds, and the Outcomes Another burgeoning area of Neolithic research concerns archaeological patterning of settlements. Large-scale settlements, in particular, are actively being discovered and have added to understanding some features of Neolithic settlements. Despite the recent increased acquisition of data, settlement analyses have not escaped existing interpretive frameworks. They have so far been limited to research on locational changes (Kong 2010), house shape and spatial structure (Bae 2007), establishing house types and their transitions (Koo 2011a; Lim 2006), and experiments on reconstructing house forms (J.-H. Kim 2010; Koo 2011b). Of course, there have been attempts to analyze these new large-scale settlement data from various angles. Of interest is the argument that the settlement system in Phase II of the Neolithic consists of three stages and that, depending upon the region, there are two, three, or four stages in Phase III (Lim 2010). Also, Ji-In Yoo (2012) analyzed newly discovered material from the mid-west coastal area to argue that large scale groups established long-term habitation in the Late Neolithic, rather than the Middle Neolithic as was asserted in preceding work.

Even though large-scale settlements are being investigated, studies examining settlement structures or systems have not been forthcoming. The main reason for the current absence of available scholarly work on these important issues is that site reports for these new projects have yet to be published. As they become available, we can expect work to develop that escapes the current interpretive framework. Researchers will be able to look at a variety of issues concerning the lives of the Neolithic people who inhabited these settlements, such as social structures and stratification, spatial organization of activities, landscapes, ideology, and so on.

Until recently, the data on Neolithic burials, in terms of both the number and scale of sites discovered, was extremely limited compared to settlement data. Tombs were mostly associated with the Middle Neolithic and later and most research was quite basic, such as examining burial types and distribution and funerary practices (Im 2008). However, a 2010 investigation of the Janghang site on Gadeuk-do Island, Busan, resulted in the discovery of a large burial ground. This site is of great significance not only in terms of scale, but also because other types of information are becoming known from there. Due to the acidic nature of the soil on the Korean Peninsula, examples of significantly represented human remains in a burial context are extremely rare, but the skeletal remains of 48 individuals have been discovered at Janghang. Eight individuals were buried in a supine position, while twenty-three appear to have been buried in a crouched position. Crouched burials are a notably different practice, since supine burials constitute the majority of previously known burials (J.-H. Kim 2011; D.-J. Lee 2011). Future additional work and significant debate surrounding this site and its skeletal remains are expected to clarify the atypical discoveries at this site.

\section{The Bronze Age and Early Iron Age}

The Establishment of the "Incipient" Bronze Age - A three-phase chronology for the Mumun pottery period of South Korea was established in the 1980s; it has been broadly adopted within Korean archaeology regardless of some dissenting opinions. This chronological scheme consists of an "Early" phase represented by pottery with decoration around the vessel mouth; a "Middle" phase represented by Songgukri type pottery; and a "Late" phase represented by attached-rim pottery. However, 
following the discovery of the "Misari cultural assemblage," characterized by stone slab hearths and pottery with notched raised bands, an "Incipient" phase was established (Ahn 2000). The majority of researchers agree with this chronological position (Cheon 2005; Jung 2013; J.-Y. Kim 2004; Ko 2009). Other scholars have expressed doubt about the existence of an "Incipient" phase, noting that in the Liaodong region or the Amnokgang River region where notched raised band pottery originated, there is no phase during which this pottery was used exclusively (J.-S. Kim 2008; Park 2009). Despite this disagreement, the Incipient-Early-Middle-Late Bronze Age chronology for the Korean Peninsula has generally come to be accepted. Early work on the Incipient phase places the time of its appearance at around the tenth century B.C.E., but various recent studies put it around the fifteenth century B.C.E. (J.-Y. Kim 2004; S.-O. Kim 2007).

The Origins of the Songguk-ri Culture and the Nature of the Middle Bronze Age Culture The Songguk-ri culture of the Korean Peninsula is considered the archetypical culture of the Middle Bronze Age, a period that witnessed significant changes in social structure, stratification, and subsistence economy. Songguk-ri culture sites are found south of the line connecting Hwaseong, Pyeongtaek, Cheongju, Sangju, Daegu, and Ulsan (Fig. 1). Thanks to in-depth research into the archaeological materials at these sites, almost all aspects of this culture are well known, including its distribution, structure, social character, and degree of stratification (B.-C. Kim 2011; J.-S. Kim 2007; S.-O. Kim 2001, 2003, 2004, 2007; Ko 2010; S.-J. Lee 2012; Woo 2010, 2013). The Songguk-ri culture is defined by the following components: houses with an ovalshaped pit in the centers of their floors (yielding jars with outwardly curved mouths), flask-shaped red burnished pottery, stone daggers with attached handles that do not have a central horizontal groove, triangular stone knives, and grooved adzes.

Even though there is significant consensus among archaeologists on most aspects of Songguk-ri culture, one contentious issue that has yet to be resolved is its origin. Hypotheses on the origins of Songguk-ri culture can be broadly divided into those that posit an external place of origin and those that assume it developed indigenously (S.-O. Kim 2006). First put forth by Hong-Jong Lee (2002), advocates of the former position maintain that the Songguk-ri culture was: (1) introduced from outside its core area; (2) first established in the mid-to-lower reaches of the Geum River; and (3) transformed through cultural contact with indigenous groups, primarily Yeoksamdong culture communities who used dolmens (H.-J. Lee 2005; J.-M. Lee 2004). The central problem with the "external origin" theory is that the external homeland from whence Songguk-ri culture is supposed to have originated has yet to be identified. This problem is acknowledged by both advocates and critics of this theory.

The position that the Songguk-ri culture developed indigenously is represented by two differing viewpoints: one sees it as having developed out of the Yeoksam-dong culture (J.-S. Kim 2003a, 2006) and the other out of the Garak-dong culture (Song 2001). Those favoring the former posit a "pre-Songguk-ri" cultural assemblage (Ahn 1992) or material culture (J.-S. Kim 2006) to establish a temporal link between the Yeoksam-dong and Songguk-ri cultures. The proposed developmental order is: Yeoksam-dong culture $\rightarrow$ pre-Songguk-ri (Hyuam-ri) culture $\rightarrow$ Songguk-ri culture. Those favoring the latter argue that Songguk-ri culture developed directly from Garak-dong culture; they consider the "pre-Songguk-ri culture" a result of cultural assimilation between Songguk-ri and Yeoksam-dong. Both "indigenous develop- 


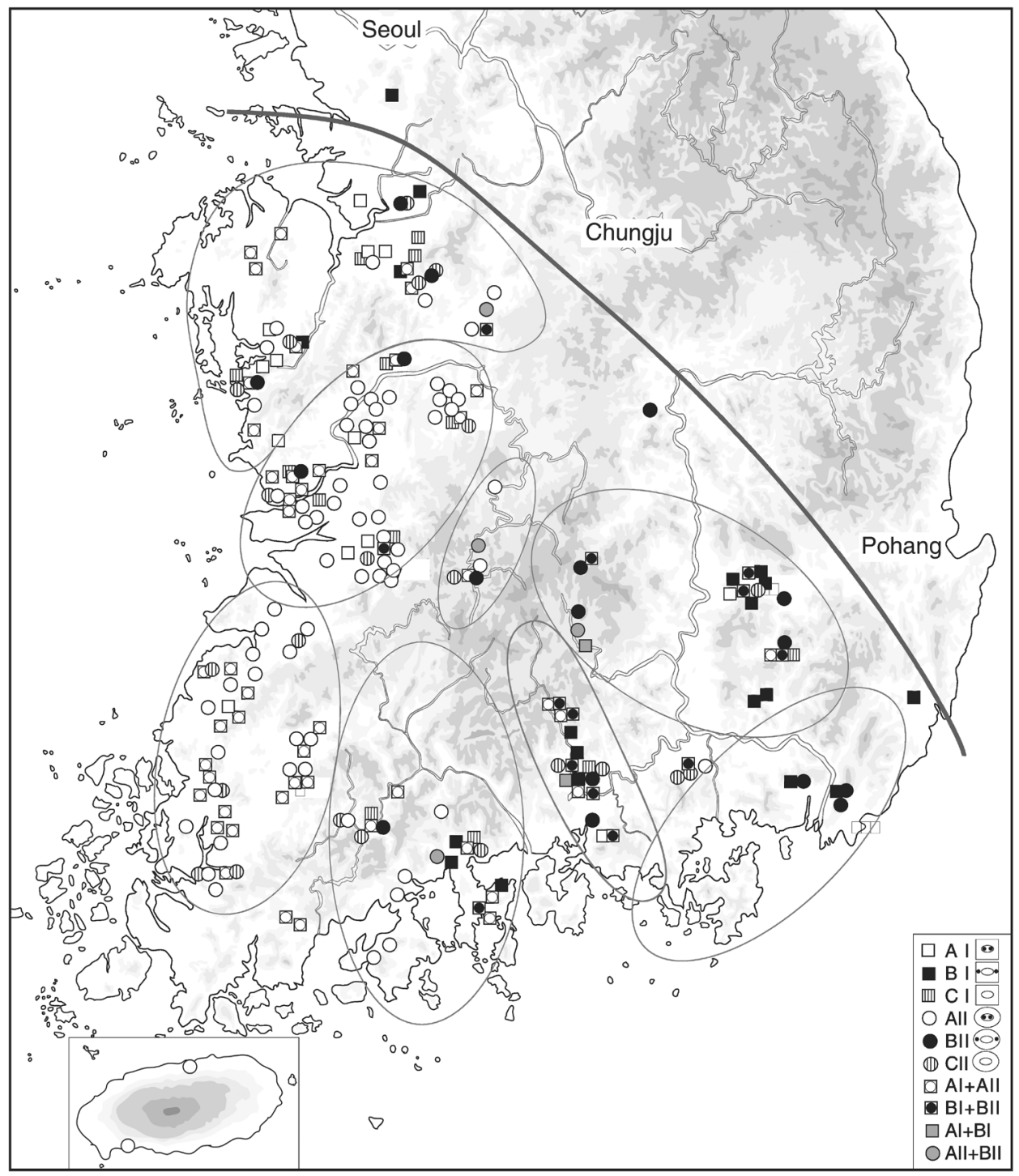

Fig. 1. Distribution of Songguk-ri settlements (S. O. Kim 2006).

ment" hypotheses have been criticized for failing to explain the fact that "preSongguk-ri" houses do not necessarily precede Songguk-ri houses in all areas. They also cannot account for the fundamental catalysts that instigated the transition from square to round houses.

A Middle Bronze Age culture different from Songguk-ri culture has been established in the lower reaches of the Han River, the eastern and western regions of Gangwon Province, and the southeast coastal region centered around Ulsan and Pohang. In these regions, the Early-Middle Bronze Age transition was accompanied by a change from large-scale rectangular houses to smaller square houses. Regional 
variations can also be seen within this non-Songguk-ri culture sphere. For example, in the western region of Gangwon Province, houses with internal postholes and a distinctive stamped clay area yielding tanged stone arrowheads have been identified; these are referred to as "Cheonjeon-ri" houses (K.-J. Kim 2008). In the southeast coastal region, houses with distinctive structures and containing pottery decorated with horizontal lines made with grain impressions have been discovered. Referred to as "Geomdan-ri" type, these houses provide evidence of strong regionality (Bae 2005; S.-H. Lee 2012).

It is difficult to establish a specific Middle Bronze Age cultural type in these regions, however. Apart from the houses becoming square and smaller in size, the rimperforated pottery and pottery with notched designs of the Early Bronze Age continued to be used, and the types and density of burials also remained similar to the Early Bronze Age. Accordingly, the regional cultures of the non-Songguk-ri culture sphere can be understood as a later type of Yeoksam-dong culture, and therefore can be referred to as "Late Yeoksam-dong" culture.

The Introduction and Characteristics of the Attached-Rim Pottery Culture - There has been much active debate surrounding the date of the introduction of the Attached-Rim Pottery culture, represented by attached-rim pottery, black burnished ware, Koreanstyle bronze daggers, bronze mirrors with fine designs, bronze spearheads, and triangular stone arrowheads. The traditional view sets the arrival of this culture at around 300 B.C.E. (Jo 2005; W.-Y. Kim 1991; Park 1993; Yi 1994), but the results of recent radiocarbon analysis (C.-H. Lee 2010) and the analysis of its archaeological features and artifacts (H.-W. Lee 2011; Park 2007) have led to a growing number of researchers who believe that the lower time limit of the Attached-Rim Pottery culture can be pushed back to 600 B.C.E. The earliest date for the Attached-Rim Pottery culture is a key issue that is also relevant to establishing a chronological division of the Bronze Age in the Korean Peninsula, exploring the relationship between the Songguk-ri culture and the Attached-Rim Pottery culture, and identifying the nature of the latter. As such, it is a question that needs to be resolved in the near future.

Regarding the route by which the Attached-Rim Pottery culture was introduced into the Korean Peninsula, there are differences of opinion on whether it was via sea or overland, but the majority of researchers seem to agree on two points: that the Korean-style slender bronze dagger culture had branched out from the Liaoning bronze dagger culture of China's northeast region, and that it was transported by migrant groups from Gojoseon (Jo 2005; Park 2000; Park 2003; Yi 1994). Various debates about the nature of the society represented by the Attached-Rim Pottery culture are ongoing. Chung-Kyu Lee (1999) has suggested the presence of three social ranks in this society, based on the type and number of artifacts in burials yielding bronze mirrors with multiple knobs, along with clustering patterns in the burials. Through a multifaceted analysis, Seung-Og Kim (2007) has argued that Dolmen society, associated with large-scale communal farming, was a group-oriented chiefdom society whereas the society of the Korean-style Slender Dagger culture, which developed a mobile mixed economy, was an individualizing chiefdom society. Man-Young Song (2011) rebuts the present opinion that sees the relationship between the incoming migrants of the Attached-Rim Pottery culture and the indigenous communities to have been one of conflict or one that led to the reorganization of one of the interacting groups. Instead, he has tried to explain the nature of society of the Attached-Rim 
Pottery culture in terms of changes in socioeconomic networks. Finally, Hee-Joon Lee (2011) has examined the foundations of chiefly power, and specific changes in the source of this power over time, arguing persuasively that in contrast to the Bronze Age, where chiefly power had an ideological basis, chiefly power in the AttachedRim Pottery period emanated more from an economic basis.

\section{TRENDS IN KOREAN PREHISTORIC ARCHAEOLOGY}

To this point I have examined, by chronological periods, the most significant developments and central debates within Korean prehistoric archaeology. In this section, I summarize and review several general research trends and directions in Korean prehistoric archaeology.

In keeping with the progression of archaeology in the rest of the world, the first research trend in Korea involves the popularity of a holistic approach that provides an explanation for the observable variations within the archaeological record by focusing on the inter-relationships between various cultural (political, economic, social, environmental, ideological) factors. Even though it is more difficult to reconstruct aspects of ritual behavior, ideology, or the human mind using prehistoric material culture than historical material, archaeologists are steadily increasing their attempts to reconstruct prehistoric culture from a holistic perspective. In Palaeolithic research, these endeavors include studies in which the stylistic attributes of hand axes are explained through symmetrical variation (Yoo and Kim 2010), inferences are made about changes in human cognitive ability (H.-W. Lee 2004), and hand axes are interpreted from various perspectives (Yi 2010a). In the case of the Neolithic, examples include studies in which mountain sites are interpreted as ritual sites related to fishing and other maritime activities (Ha 2006); the land use strategies and social relations of the hunter-gatherers of the Late Neolithic in the mid-western region have also been analyzed (J.-S. Kim 2003b). In the case of the Bronze Age, with its full-fledged development of social complexity, the number of studies undertaken from a holistic perspective are so numerous and the types of theoretical approaches so diverse that it is difficult to note all of the many recent examples (but see J.-H. Ahn 2006; J.-I. Kim 2004, 2007; K.-G. Kim 2005; S.-O. Kim 2007; S.-J. Lee 2006; S.-K. Lee 2007).

Another recent change in Korean prehistoric archaeology is a rapid increase in environmental analyses and experimental archaeology. This trend can be linked to an increase in archaeological specialists in these fields since the 1990s, but it also reflects the widening of interdisciplinary knowledge and broader research horizons of today's Korean archaeologists. Scientific archaeology is now as well developed in Korea as in other countries; environmental archaeology, soil archaeology, geoarchaeology, maritime archaeology, pollen analysis, lipid analysis, and carbon isotope analysis are no longer unfamiliar topics (and their scientific terminology no longer unknown), as an increasing number of archaeologists are specializing in these areas of analysis. The relative increase since the 1990s in attempts to incorporate experimental archaeology as an interpretive tool is indeed desirable, but unfortunately the majority of these attempts have focused on reconstructing houses, analyzing impressions on pottery (Son et al. 2010), or carrying out pottery firing experiments (Cho et al. 2010; KIAE 2007).

Since Korean archaeology's inception, the relationship among the Korean Peninsula, the northeast region of China, and the Japanese archipelago has been a topic of continued interest. Initially, Palaeolithic research was carried out through international 
research and exchange. However, the degree of interest shown over the last twenty years in Korean prehistoric archaeology, the sites and artifacts of the northeast region of China, and the Japanese archipelago, has grown so much it is no longer comparable to that which came before. Additionally, research areas of interest are continually expanding to encompass the Mongolian steppe and the Russian Primorye and Siberia, with archaeological results rapidly increasing to such an extent that they cannot be enumerated here. Encouragingly, Korean scholars are now conducting archaeological excavations outside of East Asia, in places such as Vietnam, Tanzania, Mongolia, and Azerbaijan. These sorts of changes in the geographic scale of Korean archaeological research and cross-cultural comparisons, coming about in the current atmosphere of internationalization and informatization, make it possible for Korean prehistoric archaeology to go beyond East Asia and be evaluated within the context of world archaeology.

Finally, these changes in Korean prehistoric archaeology have led to in-depth analyses and interpretations of the archaeological material of each region by local scholars. Regional and period-specific archaeological societies have become increasingly active in the discipline. Regional archaeological societies contributing to Korean archaeology include the Yeongnam Archaeological Society (founded in 1984) and the Honam Archaeological Society (founded in 1993). Prominent regional archaeological societies founded in the 2000s include the Hoseo Archaeological Society, the Seoul \& Gyeonggi Archaeological Society, and the Gangwon Archaeological Society. ${ }^{4}$ The result is that all regions of South Korea are now covered by a regional archaeological society. Furthermore, period-specific societies were established after the 1980s, including the Korean Neolithic Society (founded in 1990), the Korean Palaeolithic Society (founded in 1999), and the Korean Bronze Age Society (founded in 2007). These regional and period-specific societies have enabled conferences, workshops, and journal publications to flourish, facilitating the rapid expansion of Korean prehistoric archaeology.

\section{CONCLUSION: OUTCOMES AND THEMES}

This article has reviewed by cultural period the research outcomes and themes of the past twenty years of Korean prehistoric archaeology and highlighted general trends and trajectories of research. Over the past two decades, archaeological studies have moved beyond the traditional research topics of chronology, artifact typology, and genealogy of types. Research questions and methodologies have diversified and expanded. Korean archaeologists have developed a holistic research perspective and embraced scientific analyses; experimental archaeology has become more popular. They have also become increasingly interested in the archaeology of surrounding regions and in world archaeology as they seek to examine cultural interactions and develop comparative models for interpretation. Local archaeological societies have become more involved in regionally focused analyses. Thus, Korean prehistoric archaeology moved ahead rapidly in terms of both quantity and quality over the past twenty years.

Despite such progress, some issues still need to be resolved before a full understanding of prehistoric cultures in the region can be achieved. Korean archaeologists must further pursue theories and models related to the establishment and development of prehistoric cultures. The recent explosion in the quantity of archaeological data along 
with increasing numbers of young researchers have led to analyses of cultures on a regional scale and deeper analyses of specific artifact types. This is to be encouraged as it ensures basic data will be available for social and cultural reconstructions. Even so, there is a pressing need to utilize this abundant data to develop comprehensive theories and models that can dynamically explain the catalysts and developmental processes that drove change in prehistoric cultures. A fair number of researchers still emphasize an inductive approach, so their research methodologies tend to be limited to technological descriptions of archaeological material. Developing a problemoriented, deductive approach is necessary. With a shift toward these directions and themes, Korean prehistoric archaeology may be able to quickly achieve a standard that befits South Korea's status as a global economic power.

\section{ACKNOWLEDGMENTS}

This work was supported by research funds from Chonbuk National University in 2011 and Honam Cultural Property Research Center in 2013.

\section{NOTES}

1. For example, since the 1990 s approximately 80 archaeological units (excluding national institutes and university museums) have been established in the form of private excavation companies - around 2000 archaeologists have been hired by these companies.

2. This difficulty may be related to the continuing influence of the "multi-regional evolution" hypothesis on questions regarding Late Palaeolithic origins of modern humans in East Asia and Russia.

3. Korean archaeologists tend to use the term "Lower" interchangeably with "Early" and "Upper" with "Late."

4. Due to an overlap in research themes and archaeological data, the Seoul \& Gyeonggi Archaeological Society and the Gangwon Archaeological Society were combined in 2010 to form the Jungbu Archaeological Society.

\section{REFERENCES CITED}

Aнn, JAE-Ho

1992 A study of the Songguknian culture. Youngnam Archaeological Review 11:1-34 (in Korean).

2000 The formation of agricultural society in Korea. Journal of Korean Archaeological Society 43: 41-66 (in Korean).

2006 A Study of Bronze Age Settlements. Unpublished Ph.D. diss. Busan: Busan National University (in Korean).

Ahn, Sung-Mo

2002 Vegetable foodstuffs of the Korean Neolithic Age, in The Environment and Subsistence of the Korean Neolithic Age: 85-107. Kyoung-ju: Institute of Cultural Properties Dongguk University (in Korean).

2005 Review of Neolithic agriculture in Southern Korea. Journal of the Korean Neolithic Society $10: 7-25$ (in Korean).

2006 Beginning of agriculture and sedentary settlement in East Asia. Journal of the Korean Neolithic Society 11:25-54 (in Korean).

AN, DEOG-IM

2009 Dietary reconstruction through trace element (Ba, Sr, $\mathrm{Zn}$ ) analysis of bones from the Neolithic Yondae-do site. Journal of Korean Ancient Historical Society 66:5-26 (in Korean).

2011 Reconstructing the Neolithic diet and seasonality, Korea, using stable isotopic analysis. Dongbanghak $21: 181-214$. Institute for Eastern Classic Studies (in Korean).

An, DeOg-Im, Min SeO, and GeOn-Su Kim

2008 A study of coprolite from the Yoseodo shell midden, Korea. Journal of Korean Ancient Historical Society 60:5-19 (in Korean). 
BAe, Christopher J.

2013 Paleolithic cave home bases, bone tools, and art and symbolism: Perspectives from Korea. Hoseo Archaeology 29:59-85.

BAE, Jin-Sung

2005 Establishment of Geomdan-ri culture. Journal of Korean Ancient Historical Society 48:5-28 (in Korean).

BAE, KIDONG

1999 The Palaeolithic site and stone industry of Nachon-ri, Jinju, in The Palaeolithic Culture of the Youngnam Region: 31-46. The Youngnam Archaeological Society (in Korean).

2004 A short critical review of understandings of ground wedges at Palaeolithic sites in Korea. Journal of the Seoul-Gyeonggi Archaeology Society 3-2:5-15 (in Korean).

BAe, Sung-Hyuk

2007 Spatial structure of settlements in the Neolithic period. Journal of the Korean Neolithic Society $13: 1-28$ (in Korean).

Chang, Yong-JoON

2004 Origin of the Korean Upper Palaeolithic: Comparing early Upper Palaeolithic sites in Northeast Asia. Treatises on Korean History 104 : 1-45 (in Korean).

2013 Obsidian research of the Palaeolithic Age in Korea: Recent progress and problems. Journal of the Korean Palaeolithic Society 28:19-60 (in Korean).

Cheon, Seon-Haeng

2005 Formation and development of "Doldae Mun" pottery in Korea. Journal of the Korean Archaeological Society 57:61-97 (in Korean).

Cho, Dae-Youn, Jin Kim, and Hyun Jeong

2010 Pottery production and social transformation during the Korean Neolithic and Bronze Age. Journal of the Hoseo Archaeological Society 23:82-109 (in Korean).

Cho, Nam-Chul, and Seung-Yup Choi

2010 Provenance study of obsidian from the Gigok Palaeolithic site in Donghae-si using trace elements. Journal of the Korean Ancient Historical Society 70:5-20 (in Korean).

Cho, Nam-Chul, Hyung-Tae Kang, and Min-Su Han

2005 Characterization of the Sangmuyongri obsidian artifacts based on chemical composition and texture. Journal of the Korean Ancient Historical Society 49:5-26 (in Korean).

Cho, TAe-Sop

2000 Biological agents of bone modification from taphonomical approach. Journal of the Korean Palaeolithic Society 2:41-50 (in Korean).

2005 Taphonomy and the Fauna of Palaeolithic Korea. Seoul: Hyean (in Korean).

2013 A study of suidae fossil from Palaeolithic sites in Korea. Journal of the Korean Palaeolithic Society 27 : 75-100 (in Korean).

Choi, BoK-Kyu, and Hye-Jeong Yu

2005 The Hahwagye-ri III Jagunsolbat Palaeolithic-Mesolithic site in Hongcheon-gun County, Korea. Journal of the Korean Paleolithic Society 11:1-12 (in Korean).

Choi, ChOng-PiL

2005 Some problems with the research on the Korean Neolithic. Prehistory and Ancient History $22: 163-182$ (in Korean).

ChOi, IN-GuN

2011 A Study on the Use of Life Artifacts in the Neolithic. Unpublished M.A. thesis. Seoul: Korea University (in Korean).

ChOI, Jong-Hyuk

2005 Study of agriculture in south province of Korea-based on the composition of stone tools. Journal of the Korean Neolithic Society 10:69-86 (in Korean).

2010 Life of Tongsamdong shell-midden people. Journal of the Korean Neolithic Society 18:117-140 (in Korean).

ChOI, SAM-Yong

2001 Study of bone artifacts at Maldeung site, Baengnyung Island. Journal of the Korean Neolithic Society 2:51-62 (in Korean). 
Choi, Seung-Yup

2006 Analysis of hand axes and picks from Gangwon province. Journal of the Korean Palaeolithic Society 14:19-33 (in Korean).

2010 A Study on the Palaeolithic Culture in Gangwon Province, Korea. Unpublished Ph.D. diss. Chuncheon: Kangwon National University (in Korean).

$\mathrm{HA}, \mathrm{IN}-\mathrm{Su}$

2001 Plant remains from dwelling site No. 1 Dongsam-dong shell-middens. Journal of the Korean Neolithic Society 2:41-49 (in Korean).

2006 A study of mountaintop remains built up in the Neolithic era. Journal of Busan Museum 12:1122 (in Korean).

2010 A study of Dongsam-dong shell-midden culture. Journal of the Korean Neolithic Society 18:1-41 (in Korean).

Han, Chang-Gyun

2003 Chronological problems with Korean Palaeolithic sites. Journal of the Korean Palaeolithic Society $7: 1-40$ (in Korean).

2008 The natural environment of the Upper Palaeolithic period in Korea. Journal of the Korean Archaeological Society 66:4-47 (in Korean).

2011 The environmental background of the Upper Palaeolithic in Korea. Journal of the Korean Palaeolithic Society 23:3-29 (in Korean).

Hong, Mi-Young, And Nina Kononenko

2005 Obsidian tools and their use as excavated from the Hopyeong-dong Upper Palaeolithic site, Korea: A preliminary progress report. Journal of the Korean Palaeolithic Society 12:1-30 (in Korean).

IM, HACK-JONG

2008 Neolithic tombs. Journal of the Korean Neolithic Society 15:65-115 (in Korean).

JO, JiN-SEON

2005 A Study of the Slender Bronze Dagger Culture. Seoul: Hakyeon Munhwasa (in Korean).

JUNG, Ji-SuN

2013 A study of the early former residential area of the Nam river basin in the Bronze Age. Journal of the Society for Korean Bronze Culture 12:4-26 (in Korean).

Jwa, YONG-JoO

2013 Geochemical data and their interpretation in the study of source obsidian. Journal of the Korean Palaeolithic Society 28:3-18 (in Korean).

Kang, Chang-Hwa

2002 The formation and development of the early Neolithic culture in Jeju Island, in Archaeology of the Sea-Interchange: 9-33. Jeju: The Korean Archaeological Society (in Korean).

Kim, BumCHEOL

2011 Dwelling patterns and household developmental cycle during the early Bronze Age: With special reference to Yeoksamdong- and Heunamri-type settlements of the Hoseo region. Journal of the Korean Ancient Historical Society 72:31-60 (in Korean).

Kim, Eun-Young

2007 A study of flat-bottom pottery culture in the early Neolithic Age, focusing on the Goseong Munam-ri site. Munhwajae 40:169-205 (in Korean).

KIM, GEON-Su

2001 Seasonality of food resources at Noraeseom shell-middens. Journal of the Korean Neolithic Society 2:13-20 (in Korean).

2004a An examination of methodologies for studying shell mounds. Journal of the Korean Neolithic Society 8:99-112 (in Korean).

$2004 b$ Trap-fishery in prehistoric/ancient times in Korea: Focused upon the shell-sinker. Journal of the Honam Archaeological Society $21: 35-49$ (in Korean).

Kim, Hun-SuK

2010 Age and diet concerns regarding human remains at the Daepo shell midden. Journal of the Korean Neolithic Society 20:89-111 (in Korean).

Kim, JAE-HyeON

2011 An analysis of Neolithic human skeletal remains found in the Janghang site at Gadeok Island, Busan, in Shell Mounds Culture of the Neolithic Age: 95-101. Busan: Korean Neolithic Research Society (in Korean). 
Kim, Jae-Youn

2004 The chronology and genealogy of the "Gakmok Doldae Mun" pottery of Korea. Journal of the Korean Ancient Historical Society 46:31-70 (in Korean).

KIM, JANG-SuK

$2003 a$ The development of the Songgukri assemblage in the Chungcheong area. Journal of the Korean Archaeological Society 51:33-55 (in Korean).

$2003 b$ Land-use strategy and sharing access rights to resources during the central-western Korean Late Neolithic. Prehistory and Ancient History 18:57-74 (in Korean).

2005 Subsistence studies and shell middens of the Korean Neolithic. Journal of the Korean Neolithic Society 9:27-46 (in Korean).

2006 Pre-Songgukri material culture and the Songgukri assemblage in the Chungcheong area. Journal of the Korean Ancient Historical Society 51:43-77 (in Korean).

2007 Settlement and social complexity studies of the Korean Bronze Age. Journal of the Hoseo Archaeological Society 17:4-25 (in Korean).

2008 Reconsidering the incipient Mumun model. Journal of the Korean Archaeological Society 69:94-115 (in Korean).

Kim, JiN-HeE

2010 Restoration and experimentation on Neolithic dwelling sites: Focused on Ansan Singil-dong dwelling site No. 5. Journal of the Korean Neolithic Society 19:49-75 (in Korean).

Kim, Jong-Chan, K. Yurij, and Alla C. Vasilchuk

2002 AMS-dating of macrocyclic ground veins near Chongokni, South Korea. Journal of the Korean Palaeolithic Society 6:181-196 (in Korean).

KIM, JONG-IL

2004 Social structure and symbolic systems of Korean middle Mumun pottery culture. Treatises on Korean History 104 : 47-81 (in Korean).

2007 Beyond the rise of stratified society and rulers. Journal of the Korean Archaeological Society $63: 150-175$ (in Korean).

Kim, Ju-Yong, Heon-Jong Lee, and Dong-Yoon Yang

2002 Quaternary formation, environment, and chronology of some Palaeolithic sites in South Korea. Journal of the Korean Palaeolithic Society 6:165-180 (in Korean).

KIM, KwON-GU

2005 The Bronze Age Farming Society of the Yeongnam Region. Seoul: Hakyoun Munhwasa (in Korean).

Kim, Kwon-Jung

2008 The transitional Bronze Age dwelling sites and settlement structure of Gangwon Yeongseo, in Settlement Studies of Korea and Japan: 91-104. Seoul: The Society for Settlement Studies of Korea and Japan (in Korean).

KIM, SANG-TAE

2011 A Study of the Lithic Assemblage of the Lower-Middle Palaeolithic in Korea. Unpublished Ph.D. diss. Kangwon National University, Chuncheon (in Korean).

Kim, Seung-Og

2001 A study of Songgungni-type burials in the Kum-gang River basin. Journal of the Korean Archaeological Society 45:45-74 (in Korean).

2003 Typological classification and changes in Mumun period burials found in the upper Kumgang river basin. Journal of the Korean Archaeological Society 49:5-45 (in Korean).

2004 Social organization and changes in the Mumun period culture found in the Youngnam-dam area. Journal of the Honam Archaeological Society 19:63-95 (in Korean).

2006 The development and regional interactions of Songgungni-type assemblages in Korea. Journal of the Honam Archaeological Society $24: 33-64$ (in Korean).

2007 Social organization and change during the Bronze Age based on analysis of tomb data, in The Rise of Stratified Society and Rulers: 61-139. Seoul: Sahoe Pyoungron and the Korean Archaeological Society (in Korean).

KIM, WON-YONG

1991 Introduction to Korean Archaeology, 3rd ed. Seoul: Iljisa (in Korean).

KIM, YEON-Ju

2011 A Study of the Hand Axe Type of the Middle Palaeolithic Age in Gangwon Province. Unpublished M.A. thesis. Kangwon National University, Chuncheon (in Korean). 
Ko, Min-Jung

2009 A study on parallel relationships between Gangmokdoldaemun pottery culture in the Nam river basin and North Korea, in The Bronze Age of North Korea: 59-93. Busan: Society for Korean Bronze Culture (in Korean).

2010 A study of settlement structure in the Nam river region during the Late Bronze Age. Youngnam Archaeological Review 54:5-42 (in Korean).

Kong, Min-Kyu

2010 A study of the location of Neolithic sites in the midwest coastal zone. Journal of the Soongsil Historical Society $25: 5-44$ (in Korean).

KoO, JA-Jin

2004 A study of pottery and stone tools from the Daecheon-ri Neolithic site. Journal of the Hoseo Archaeological Society 11:73-109 (in Korean).

2011 a A review of types of settings for Neolithic dwelling sites. Journal of the Soongsil Historical Society 26:5-41 (in Korean).

$2011 b$ The restoration and meaning of Neolithic dwellings. The Journal of Korean Field Archaeology $10: 5-36$ (in Korean).

KiAE (Korean Institute for ArChaeology \& EnVironment)

2007 Archeology of Ceramic Firing Techniques. Seoul: Seokyung Munhwasa.

Lee, Chang-Hee

2010 Calendar date of ring-rimmed pottery: Appearance dates of slim bronze dagger culture and ironware. Munhwajae 43-3: 48-101 (in Korean).

Lee, Choong-Min

2011 A Study of Mammalian Fossils from Neolithic Sites in Korea. Unpublished M.A. thesis. Yonsei University, Seoul (in Korean).

Lee, Chung-Kyu

1999 A study of bronze mirrors with geometrical designs in Korea, Japan, and northeast China. Journal of the Korean Archaeological Society 40:57-87 (in Korean).

LeE, DONG-Ju

2011 The status and challenge of studying the Neolithic Age using recent data from the southern region. Journal of the Korean Neolithic Society 22:93-127 (in Korean).

LEE, EuN

2010 A Study of Livelihood Activities in the Korean Peninsula during the Neolithic Age: Focused on Faunal Remains Excavated from Shell Mounds. Unpublished M.A. thesis. Mokpo National University (in Korean).

LEE, GI-KIL

1999 An analysis of tanged point and associated artifacts, in The Palaeolithic Culture of the Youngnam Region: 83-96. Daegu: Youngnam Archaeological Society (in Korean).

2011 Analysis of technique, typology, and measurement of tanged points from the Jingeuneul prehistoric site in Korea. Journal of the Korean Ancient Historical Society 73:5-30 (in Korean).

Lee, Gyoung-Ah

2005 Review of perspectives on Korean Neolithic cultivation based on archaeobotanical remains. Journal of the Korean Neolithic Society 10:27-49 (in Korean).

Lee, Gyoung-Ah, Ho-Pil Yun, Min-Jung Ko, and Chun-Young Kim

2011 Plant use in the Nam river valley during the Neolithic period. Youngnam Archaeological Review 56:5-42 (in Korean).

LEE, HeE-JoON

2011 On the power of chieftains and their transformation from the Bronze Age to the Proto-Three Kingdoms period in the southern Korean peninsula. Youngnam Archaeological Review 58:35-77 (in Korean).

LEE, HEON-JONG

2000 A study of Middle Palaeolithic culture in Northeast Asia. Journal of the Korean Ancient Historical Society $33: 7-48$ (in Korean).

$2002 a$ A study of the conservative character and persistence of the pebble tool tradition in Korea. Journal of the Korean Ancient Historical Society 38:27-52 (in Korean).

$2002 b$ A study of major characteristics of the Upper Palaeolithic culture in the Honam area. Journal of the Honam Archaeological Society 16:5-24 (in Korean). 
2004 Correlation of chronology with techno-typological character for the Upper Palaeolithic in Korea. Journal of the Korean Ancient Historical Society 44:5-22 (in Korean).

Lee, Heon-Jong, And Dae-Hoon Jang

2011 A study on the function and restoration of tanged tools in the Upper Palaeolithic of Korea. Journal of the Korean Palaeolithic Society 23:103-120 (in Korean).

LeE, HONG-Jong

2002 Time-space differences in Songguk-ri culture. Journal of the Hoseo Archaeological Society 6-7: 77-103 (in Korean).

2005 Cultural contact and change in Songgukri culture. Journal of the Korean Ancient Historical Society 48:29-50 (in Korean).

LeE, HyeOng-Woo

2003 Understanding hand axes with metrical analysis. Journal of the Honam Archaeological Society 18:5-25 (in Korean).

2004 An archaeological view on evolutionary hominid cognition. Journal of the Korean Ancient Historical Society 45:5-30 (in Korean).

LeE, Hyung-Won

2011 The chronology and spatial characteristics of the pottery with clay stripes culture originating from central-south Korea. Journal of the Hoseo Archaeological Society 24:58-93 (in Korean).

LEE, JIN-Min

2004 A study of the relationship between Yeoksamdong and Songgungni assemblages in central Korea. Journal of the Korean Archaeological Society 54:35-62 (in Korean).

LEE, JUNE-JEONG

2002a Methodological considerations for shell analysis. Journal of the Korean Neolithic Society 4:5-25 (in Korean).

$2002 b$ Functional variation of shell midden patterns in southern Korea. Journal of the Korean Archaeological Society 46:53-80 (in Korean).

2003 Deer hunting, butchering, and transport in prehistoric Korea: An analysis of a skeletal part-profile at the Tongsam-dong Site. Journal of the Korean Archaeological Society 50:5-30 (in Korean).

2011 Intensification of millet and rice agriculture in Korea: Evidence from stable isotopes. Journal of the Korean Ancient Historical Society 73:31-66 (in Korean).

LEE, SANG-KIL

2007 Emergence of political power in terms of ancestral rites, in The Rise of Stratified Society and Rulers: 179-220. Seoul: Sahoe Pyoungron and the Korean Archaeological Society (in Korean).

LeE, SOO-Hong

2012 Archaeological Study of Kumdan-ri Type in the Bronze Age. Ph.D. diss. Busan National University in Busan (in Korean).

LeE, Sung-Joo

2006 Problems with archaeological approaches to Bronze Age society. Korean Antiquity 68:7-24 (in Korean).

2012 Rituals, monuments, and the development of individualized burials. Journal of the Hoseo Archaeological Society 26:74-109 (in Korean).

LEE, YeONG-DEOK

2006 The possibility of diving fishery using a fish harpoon in the Neolithic Age. Journal of the Korean Neolithic Society $11: 129-140$ (in Korean).

Lee, Yung-Jo, And TAe-Sop Cho

2003 A study of the hunting economy of Palaeolithic people in Korea. Prehistory and Ancient History 18:5-24 (in Korean).

Lee, Yung-Jo, Nam-Chul Cho, and Hyung-Tae Kang

2004 Characteristic analysis of obsidian artifacts from the Suyanggae site in Korea. Journal of the Korean Palaeolithic Society 10:25-35 (in Korean).

LeE, Yung-Jo, ANd Su-Jin Kong

2002 New analysis results of Suyanggae tanged tools in Korea. Journal of the Korean Palaeolithic Society $6: 11-24$ (in Korean).

LiM, SANG-TEAK

2006 Changes in the intra-site patterns during the Chumun period. Journal of the Honam Archaeological Society $23: 55-83$ (in Korean). 
2010 Settlement systems of Neolithic period in the Korean Peninsula: Variations in time and space. Journal of North-east Asian Culture 24 : 135-150 (in Korean).

2012 Pottery styles and their archaeological implication: Initial phase of the Neolithic period on the eastern and southern coasts of Korea. Journal of the Korean Neolithic Society 24:1-30 (in Korean).

Norton, Christopher J., Kidong Bae, John W. K. Harris, and Han-Yong Lee

2006 Middle Pleistocene handaxes from the Korean Peninsula. Journal of Human Evolution $51: 527-$ 536.

PARK, JIN-IL

2000 A study of pottery with round clay stripes culture: Focused on the Hoseo and Honam areas. Journal of the Honam Archaeological Society 2:125-161 (in Korean).

2007 Roll-rimmed vessels of the Bronze Age and Early Iron Age. Journal of Korean Bronze Culture $1: 84-114$ (in Korean).

PARK, SOON-BAL

1993 A short discussion of the cultural process of Korean Early Iron culture. Bulletin of Archaeology and Art History 3:37-62. Cheongju: Chungbuk National University (in Korean).

2003 Settlement processes of the pottery with round clay stripes culture, in The 49th Conference of The Korean Association of University Museums, 16-18 October, Seoul, Korea: 57-75. Seoul: Korean Association of University Museums (in Korean).

PARK, Sun-Ju

1999 The Origins and Evolution of Human Beings. Cheongju: Chungbuk National University Press (in Korean).

Park, Sung-HeE

2009 A critical approach to "Doldaemun" pottery of the incipient period of the Korean Bronze Age. Journal of the Gangwon Archaeological Society 12-13:5-21 (in Korean).

Park, Young-Chul

2001 A study on and issues with the development of the Palaeolithic in the Honam region, in The Palaeolithic Culture of the Honam Region: 87-94. Iksan: The Honam Archaeological Society (in Korean).

2002 Analytical study of lithic material from the Middle Palaeolithic cultural layers in southern Korea. Journal of the Korean Palaeolithic Society 5:1-58 (in Korean).

Seong, Chun-Taek

2002 Issues in lithic use-wear studies. Journal of the Korean Palaeolithic Society 6:61-76 (in Korean).

2003 Raw material exploitation and use in Palaeolithic technology: A preliminary analysis of terminal Pleistocene lithic raw material in Korea. Journal of the Korean Ancient Historical Society 39: 1-18 (in Korean).

2004 The chronostratigraphy of Korean Late Palaeolithic sites revisited. Journal of the Korean Ancient Historical Society 46:5-30 (in Korean).

2006 A comparative and evolutionary approach to Korean Palaeolithic assemblages. Journal of the Korean Ancient Historical Society $51: 5-41$ (in Korean).

Son, Joon-Ho, Daisuke Nakamura, and Arata Momohara

2010 Research using the replication method on plant impressions found on Bronze Age pottery. The Journal of Korean Field Archaeology 8:5-34 (in Korean).

SONG, Eun-SOOK

2010 The diffusion process of Korean comb-pattern pottery, in Migrational Archaeology: 38-57. Seoul: Sahoe Pyeongron and The Korean Archaeological Society (in Korean).

Song, MAn-Young

2001 Structure and change during the early agricultural period of South Korea, in The Formation of Korean Farming Culture: 75-108. Busan: The Korean Archaeological Society (in Korea).

2011 The structure and nature of settlement during the clay-band rim pottery phase of the central region. Journal of the Korean Archaeological Society 80:29-62 (in Korean).

WoO, JUNG-Youn

2010 Symbolic meaning of Songgungni-type burials from the middle of the Gum river basin. Journal of the Hoseo Archaeological Society $25: 25-65$ (in Korean).

2013 A study of prestige and value structures amongst Songgungni-assemblage societies from the middle of the Gum river basin. Journal of the Korean Archaeological Society 84:30-61 (in Korean). 
Yi, Kun-MoO

1994 Features of Korean-type bronze dagger culture and the background of its appearance, in Bronze Culture of East Asia: 155-182. Daejeon: National Research Institute of Cultural Heritage (in Korean).

2000 The direction of Korean archaeology in the 21st century: Prehistoric parts, in The Direction of Korean Archaeology in the 21st Century: 9-26. Seoul: The Korean Archaeology Society (in Korean).

Yi, SEON-BOK

1999 A study of stone industry during the Korean Palaeolithic, in The 4th International Symposium: Suyanggae and Her Neighbours, 7-13 November, Danyang, Korea: 37-50. Cheongju: Institute of Korean Prehistory (in Korean).

2000 Chronology and stratigraphy of the Korean Palaeolithic. Journal of the Korean Archaeological Society 42:1-22 (in Korean).

2001 Middle-Upper Palaeolithic transition in Korea: A brief review. Journal of the Korean Palaeolithic Society 4:17-24 (in Korean).

$2010 a$ Radiocarbon age of the basalt plain in the Imjin basin: Archaeological implications. Journal of the Korean Palaeolithic Society 22:3-20 (in Korean).

$2010 b$ On hand axes from the Imjin River basin: Retrospect and prospects. Journal of the Korean Palaeolithic Society 19:3-18 (in Korean).

2011 On the age and depositional characteristics of the Jeongok-ri Palaeolithic site. Journal of the National Museum of Korea 17:9-27 (in Korean).

YoO, Ji-IN

2012 A study on the settlements of the Middle and Late Neolithic period in central-western Korea. Journal of the Korean Archaeological Society 85:4-41 (in Korean).

Yoo, Yong-WoOK, AND Dong-Wan Kim

2010 Symmetry in hand axes from the Imjin-Hantan river area: Dynamics observed and factors explored. Journal of the Korean Archaeological Society 75:4-45 (in Korean).

Yu, Mi-Yeon, Chang-Hee Lee, Myung-Jin Kim, Sang-Hoon Bae, and Chang-Gyun Han

2010 Material analysis and geoarchaeological interpretation of the obsidian artifact collected at Daebak-ri site, Cheongyang, Korea. Journal of the Korean Palaeolithic Society 21:21-38 (in Korean).

\section{ABSTRACT}

The aim of this article is to examine the developments and debates that have taken place in Korean prehistoric archaeology since the 1990s. In order to do this, this article first examines the trends and developments of archaeological research by period, after which the directions and trends observed throughout all periods of Korean prehistoric archaeology are synthesized. This survey emphasizes that research has begun to go beyond the traditional topics of Korean prehistoric archaeology, such as chronology, typology, and the genealogy of types, toward a diversification of subjects and the deepening of research methodology. Additionally, other trends are documented, such as the development of a holistic research perspective, the popularity of scientific analysis and experimental archaeology, a growing interest in the regions surrounding the Korean Peninsula, a greater awareness of foreign archaeological research, and the deepening of cultural analysis at a regional scale. KEYWORDS: Korea, prehistoric archaeology, archaeological method, theoretical trends. 